\title{
Konsep Akomodasi Wisata Halal di Propinsi NTB Berdasarkan Peraturan Daerah Nomor 2 Tahun 2016 Tentang Pariwisata Halal
}

\author{
${ }^{1}$ Ady Supyadi, ${ }^{2}$ Hilman Syahrial Haq, ${ }^{3}$ Hamdi \\ 1,2,3Universitas Muhammadiyah Mataram, Mataram, Indonesia \\ 1adysupyadi@gmail.com, 2hilmansyahrial@gmail.com, ${ }^{3}$ hamdi@gmail.com
}

\begin{tabular}{|c|c|}
\hline Article Info & bstract \\
\hline $\begin{array}{l}\text { Article History } \\
\text { Received: July 12, } 2018 \\
\text { Accepted: September 30, } \\
2018\end{array}$ & \multirow{2}{*}{$\begin{array}{l}\text { Islamic economy is instrumental to global economy to date. There are seven } \\
\text { sectors of Islamic economy that has improved significantly, namely culinary, } \\
\text { monetary, insurance industry, fashion, cosmetics, pharmacy, entertainment, } \\
\text { and tourism, all of which bear halal concept in their products. This research } \\
\text { study aimed to explore and analyze the description of tourist } \\
\text { accommodation in Lombok before and after the issuance of West Nusa } \\
\text { Tenggara Provincial Regulation Number } 2 \text { of } 2016 \text { on Halal Tourism and } \\
\text { examine the efforts the government has made to materialize halal } \\
\text { accommodation mandated by the regulation. This research is normative } \\
\text { legal, i.e., legal research that analyzes rules or norms related to the issue } \\
\text { being investigated. Data obtained from this research were analyzed using } \\
\text { legal interpretation methods, including extensive interpretation and } \\
\text { sociological or teleological interpretation. The findings revealed that before } \\
\text { the issuance of Provincial Regulation Number } 2 \text { of } 2016 \text {, the management of } \\
\text { tourism in West Nusa Tenggara was conventional as opposed to sharia- } \\
\text { based management upon the issuance of the regulation. In order to } \\
\text { materialize halal accommodation the government has reviewed the master } \\
\text { plan of tourism development and improved services and accommodation for } \\
\text { domestic and international tourists. }\end{array}$} \\
\hline $\begin{array}{l}\text { Keywords } \\
\text { Concept of Accommodation; } \\
\text { Halal Tourism; West Nusa } \\
\text { Tenggarar Province; } \\
\text { Provincial Regulation. }\end{array}$ & \\
\hline & \\
\hline
\end{tabular}

\section{PENDAHULUAN}

Salah satu data time series adalah lama sinar matahari. Data ini direkap oleh Ekonomi Islam adalah bagian penting dari ekonomi global saat ini. Ada tujuh sektor ekonomi Islam yang telah meningkat secara signifikan, yaitu kuliner, keuangan Islam, industri asuransi, fesyen, kosmetik, farmasi, hiburan, dan pariwisata, di mana keseluruhan sektor itu mengusung konsep halal dalam setiap produknya.

Dahulu produk halal yang dibayangkan hanya produk makanan, minuman, obatobatan dan kosmetika yang tidak mengandung alkohol atau bahan kimia yang mengandung unsur babi, darah dan bangkai. Namun sekarang telah terjadi evolusi dalam industri halal hingga ke produk keuangan (seperti perbankan, asuransi, dan lainlain) hingga ke produk lifestyle (travel, hospitalitas, rekreasi, dan perawatan kesehatan). Sektor ekonomi Islam yang telah mengalami pertumbuhan yang signifikan dalam produk lifestyle di sektor pariwisata adalah pariwisata syariah. Sebagai industri tanpa asap, pariwisata terus mengalami perkembangan yang luar biasa dari yang bersifat konvensional (massal, hiburan, dan hanya sightseeing) menjadi mengarah pada pemenuhan gaya hidup (lifestyle). Trend wisata syariah sebagai salah satu pemenuhan gaya hidup saat ini telah menjadi kekuatan pariwisata dunia yang mulai berkembang pesat. 
Bagaimana dengan kondisi industri pariwisata syariah di Indonesia? Kondisi pariwisata syariah di Indonesia masih belum maksimal. Padahal jika digarap lebih serius, potensi pengembangan wisata syariah di Indonesia sangat besar. Belum banyak biro perjalanan yang mengemas perjalanan inbound dengan paket halal travel, tetapi lebih banyak pengemasan perjalanan outbound seperti umrah dan haji. Berdasarkan data dari Badan Pusat Statistik dan Pusat Data dan Informasi Kementerian Pariwisata, angka wisatawan dari beberapa negeri Timur Tengah berdasarkan kebangsaan, yaitu Bahrain sebesar 98 orang pada tahun 2013 menjadi 99 orang pada tahun 2014 (naik 1,02 persen), Mesir sebesar 675 orang pada tahun 2013 menjadi 733 orang pada tahun 2014 (naik 8,59 persen), dan Uni Emirat Arab sebesar 1.322 orang menjadi 1.428 orang (naik 8,02 persen), sedangkan Arab Saudi mencatat angka pertumbuhan turun 3,90 persen dari 7.522 orang (tahun 2013) menjadi 7.229 orang tahun 2014 (Kempar, 2015). Jika dilihat dari angka jumlah kunjungan wisman muslim memang dinilai cukup kecil. Namun, target wisata syariah sebenarnya bukan hanya wisatawan muslim, tetapi juga wisatawan non muslim. Karena pada hakekatnya wisata syariah hanyalah sebagai pelengkap jenis wisata konvensional. Sebagai negara dengan penduduk muslim terbesar di dunia.

Salah satu tujuan wisata di Indonesia yang akhir-akhir ini menjadi perbincangan publik baik melalui media cetak maupun elektronik ialah pulau lombok. Pulau ini berada di Propinsi Nusa Tenggara Barat dengan luas wilayah $4.738 .7 \mathrm{~km} 2$. Pulau ini terdiri dari lima wilayah administratif yaitu Kabupaten Lombok Barat (1053,87 km2), Kabupaten Lombok Tengah (1208,40 km2), Kabupaten Lombok Timur (1605,55 km2), Kabupaten Lombok Utara $(809,53 \mathrm{~km} 2)$ dan Kota Mataram $(61,30 \mathrm{~km} 2)$. Di mana masing-masing wilayah administratif memiliki destinasi unggulan seperti Lombok Timur dengan Geopark Rinjani, Lombok Tengah dengan Pantai Kuta, Lombok Barat terkenal dengan pantai senggigi, Lombok Utara dengan daya tarik 3 gili serta Kota Mataram yang menawarkan konsep wisata urban. Selain potensi tersebut Pulau Lombok juga menawarkan wista religi dengan icon Islamic Center Lombok Hubbul Wathan yang didirikan pada tahun 2016 di atas tanah seluas 6,7 Ha yang merupakan masjid terbesar dan termegah di propinsi Nusa Tenggara Barat. Pendirian masjid ini semakin menggukuhkan Lombok sebagai pulau seribu masjid. Oleh karena itu, memperhatikan kondisi yang demikian, maka Pemerintah Propinsi Nusa Tenggara Barat pada Tahun 2016 mengeluarkan Peraturan Daerah Nomor 2 Tahun 2016 tentang Pariwisata Halal. Perda tersebut memberikan landasan yuridis terhadap pengelolaan pariwisata di pulau lombok. Salah satu konsekuensi dari di canagkannya pariwisata halal ialah ketersediaan akomodasi yang sesuai dengan amanat Pasal 13 Ayat 1 Peraturan Daerah Propinsi Nusa Tenggara Barat Nomor 2 Tahun 2016 yang menghendaki akomodasi jugaa berbasis pada konsep wisata halal.

\section{METODE}

Jenis penelitian ini merupakan penelitian hukum normatif yaitu Penelitian hukum untuk mengkaji kaidah-kaidah atau norma hukum yang berhubungan dengan masalah yang diteliti. Data-data yang diperoleh dalam penelitian ini selanjutnya dianalisis dengan menggunakan metode penafsiran hukum. Adapun penafsiran hukum yang digunakan yaitu penafsiran ekstentif dan penafsiran sosiologi atau teleologis. 


\section{HASIL DAN PEMBAHASAN}

Deskripsi Akomodasi Pariwisata Di Lombok Sebelum Dan Sesudah Lahirnya Peraturan Daerah Propinsi Nusa Tenggara Barat Nomor Tahun 2016 Tentang Pariwisata Halal

a) Deskripsi Akomodasi Pariwisata Di Lombok Sebelum Lahirnya Peraturan Daerah Nomor 2 Tahun 2016 tentang Pariwisata Halal.

Dalam konteks pengertian wisata halal yang melayani kebutuhan dasar wisatawan muslim mulai dari makanan dan minuman yang memiliki jaminan halal, tempat tinggal dengan fasilitas ibadah, daerah tujuan wisata atau destinasi yang dilengkapi fasilitas ibadah seperti adanya masjid maupun musholla, perlengkapan sholat dan yang lainnya secara bertahap dilakukan di Lombok.

Sebagai salah satu destinasi prioritas nasional dalam pembangunan wisata halal, di Pulau Lombok ada kawasan Mandalika dan Sekitarnya dijadikan sebagai salah satu destinasi wisata halal dengan visi World's Best Halal Tourism and Cruise Destination dengan tujuan untuk menjadikan kawasan tersebut sebagai salah satu pilihan tempat wisata halal terbaik dunia, khususnya wisatawan muslim dan mampu menjadi pintu masuk dalam menarik 1 juta kunjungan wisatawan mancanegara pada tahun 2019, dengan target pasar wisatawan mancanegara yaitu: Malaysia, Singapura, Brunei, Thailand, Taiwan, Jepang, Negara-Negara di Kawasan Timur Tengah, Eropa, Tiongkok, Amerika Serikat. Serta Daya Tarik Wisata (DTW) meliputi: Danau Segara Anak, Puncak Gunung Rinjani, Sumber Air Panas, Lava, Hutan, Air Terjun, Flora dan Fauna, Tenun, Peresean, Gendang Beleq, Ngayu-Ngayu.

Beberapa langkah yang ditempuh untuk mewujudkan visi tersebut yaitu: membenahi aksesibilitas dengan meningkatkan konektivitas pelabuhan laut antar pulau yang ada di Lombok seperti Pelabuhan Lembar dan Pelabuhan Kayangan, untuk menarik wisatawan manca negara dianggap perlu akses laut pelabuhan cruise dan marina di kawasan Mandalika terutama menarik wisatawan melalui cruise dan yacht.

Amenitas atau fasilitas penunjang menjadi sesuatu yang penting dalam pengembangan suatu wisata, seperti fasilitas kesehatan dan keselamatan dengan standar internasional merupakan kunci keberhasilan dari pengembangan kawasan wisata NTB. Pemerintah NTB selalu melakukan review master plan dan penyusunan perencanaan secara rinci, kemudian membangun kawasan cultural village, membangun dermaga untuk nelayan, membangun kawasan konservasi mangrove, membangun pelabuhan cruise dan marina beserta fasilitas penunjang, mengembangkan kargo logistik di Bandara Internasional Lombok, meningkatkan fasilitas kesehatan dan keselamatan dengan standar internasional dan membangun Sekolah Tinggi Pariwisata Lombok.

Beberapa dukungan pembangunan infrastruktur dilakukan yaitu, pengembangan, pengelolaan sarana air dengan membuat jaringan irigasi, rawa, waduk, embung situ, dan penampung air lainnya, serta penyediaan air baku di kota Mataram sebesar Rp. 39,2 Miliar, sebesar Rp. 25,7 Miliar untuk pemeliharaan, pelebaran, rekonstruksi dan rehabilitasi jalan sepanjang $88 \mathrm{~km}$ di Kota Mataram, pengembangan kawasan pemukiman, sistem penyediaan air minum dan penyehatan lingkungan di Kota Mataram sebesar Rp. 10,9 Miliar.

Penataan bangunan sebesar Rp. 4,8 Miliar, serta Rp. 20,9 Miliar untuk meningkatkan fasilitas darat, subsidi angkutan jalan perintis. Untuk meningkatkan fasilitas pelabuhan penyebrangan Lembar sejumlah Rp. 4 Miliar dan pengembangan Bandara Salahuddin Bima Rp. 24,6 Miliar, serta membangun Bandara Kaharuddin Rp. 32 Miliar.

Optimisme ditunjukkan dengan keseriusan pembangunan kawasan wisata yang ada di Nusa Tenggara Barat, terutama KEK Mandalika sebagai destinasi yang diharapkan 
mampu membantu menyumbangkan dengan maksimal untuk menarik kunjungan wisatawan manca negara sebanyak-banyaknya demi tercapainya visi 20 juta wisatawan manca negara pada tahun 2019 dengan mengembangkan aksesibilitas, amenitas, atraksi, yang menjadi fokus dalam pembangunan pariwisata.

Untuk mewujudkan visi pariwisata NTB, Pulau Lombok dijadikan sebagai destinasi wisata yang diharapkan menjadi pintu gerbang untuk menarik kunjungan wisatawan, terutama wisatawan muslim, terlebih dalam konteks wisata halal, Lombok dinobatkan sebagai wisata halal terbaik dunia dua tahun berturut-turut, yakni pada tahun 2015 dan tahun 2016 di Abu Dhabi, maka dari itu beberapa langkah strategis yang dilakukan dalam pengembangan pariwisata Lombok sebagai Kawasan Strategis Pariwisata Daerah (KSPD). Dalam Rencana Induk Pariwisata Berkelanjutan Pulau Lombok 2015-2019 dengan strategi membangun 4 pilar pariwisata, yaitu: Destinasi, Pemasaran, Industri, dan Kelembagaan dan SDM.

b) Deskripsi Akomodasi Pariwisata Di Lombok Pasca Lahirnya Peraturan Daerah Nomor 2 Tahun 2016 tentang Pariwisata Halal.

Propinsi Nusa Tenggara Barat sebagai salah satu daerah yang memiliki potensi di sektor kepariwisataan, juga melakukan pengembangan wisata halal ini yang kiranya dapat menarik wisatawan mancanegara dari Timur Tengah dan Asia. Pariwisata Indonesia tengah bergembira, karena The World Halal Travel Summit/Exhbition 2015 (WHTS15) di Abu Dhabi, Uni Emirate Arab (UEA) telah mengumumkan bahwa Indonesia, tepatnya Lombok, menjadi salah satu destinasi wisata halal terbaik, yaitu mendapat penghargaan World's Best Halal Tourism Destination dan World's Best Halal Honeymoon Destination," ujar penjelasan Perda 2/2016 yang disahkan pada 21 Juni 2016 lalu. Sehingga Nusa Tenggara Barat (NTB) menjadi provinsi pertama di Indonesia yang memiliki Perda Pariwisata Halal.

Perda tersebut mengatur berbagai jenis wisata halal, mulai dari Spa, Sauna hingga Pramuwisata. Berdasarkan Bunyi ketentuan Pasal 1 huruf 16 Peraturan Daerah Nusa Tenggara Barat Nomor 2 Tahun 2016 tentang Parwisata Halal menyebutkan bahwa :

"Pariwisata Halal adalah kegiatan kunjungan wisata dengan destinasi dan industri pariwisata yang menyiapkan fasilitas produk, pelayanan, dan pengelolaan pariwisata yang memenuhi syariah"

Dalam Perda tersebut, industri pariwisata halal meliputi akomodasi, biro perjalanan, restoran dan spa. Pengelolaan industri pariwisata halal mengikuti ketentuan yang ditetapkan oleh DSN-MUI. Akomodasi standar syariah harus memenuhi: (1) Tersedia fasilitas yang layak untuk bersuci; (2) Tersedia fasilitas yang memudahkan untuk beribadah; (3) Tersedia makanan dan minuman halal; (4) Fasilitas dan suasana yang aman, nyaman dan kondusif untuk keluarga dan bisnis; dan (5) Terjaga kebersihan sanitasi dan lingkungan.

Di dalam ketentuan Perda tersebut menyebutkan "Penyedia makanan dan minuman bersertifikasi halal wajib menjamin kehalalan makanan/minuman yang disajikan, mulai dari penyediaan bahan baku sampai proses penyajian yang dibuktikan dengan sertifikat halal," demikian bunyi Pasal 15 ayat 2.

Perda Pariwisata Halal juga mengatur tempat Spa, Sauna dan Griya pijat. Pengusaha tempat wisata itu diwajibkan untuk menyediakan: (1) Ruangan perawatan untuk pria dan wanita yang terpisah; (2) Terapi pikiran (mind therapy) dan terapi olah fisik tidak mengarah pada pelanggaran syari'ah; (3) Terapis pria khusus untuk pria dan terapis wanita khusus untuk wanita; dan (4) Sarana yang memudahkan untuk salat.

Selanjutnya di dalam bunyi Pasal 17 Perda Nomor 2 Tahun 2016 tentang pariwisata halal "Setiap pengusaha spa, sauna dan griya pijat halal wajib menggunakan produk berlogo halal resmi serta Diatur pula syarat seseorang menjadi pramuwisata yaitu (1) 
Memahami dan mampu melaksanakan nilai-nilai syariah dalam menjalankan tugas; (2) Berakhlak baik, komunikatif, ramah, jujur dan bertanggung jawab; (3) Berpenampilan sopan sesuai dengan nilai dan etika Islami; dan (4) Memberikan nilai-nilai Islami selama dalam perjalanan wisata.

Deskripsi akomodasi pariwista di Lombok Pasca Lahirnya Peraturan Daerah Nomor 2 Tahun 2016 tentang Pariwista Halal adalah berawal dengan diitunjuknya NTB sebagai salah satu daerah prioritas pembangunan pariwisata halal nasional, NTB kemudian menjadikan daerah Lombok menjadi tujuan wisata halal yang dianggap daerah ini memiliki kesiapan yang baik berdasarkan tiga penilaian utama pariwisata yang dilakukan Kementerian Pariwisata Republik Indonesia masa Pemerintahan Presiden Joko Widodo , yaitu: (1) Produk, ini terkait usaha pariwisata halal dan daya tarik wisata (alam, budaya, buatan); (2) Sumber Daya Manusia (SDM) dan Kelembagaan, mayoritas penduduk beragama islam, sehingga mudah untuk menyesuaikan kriteria-kriteria sesuai standarisasi wisata halal dunia, kemudian melakukan pendidikan terhadapmasyarakat dan pelaku usaha wisata sesuai dengan sasaran dan standar kompetensi yang dibutuhkan wisatawan muslim, melalui Dinas Kebudayaan dan Pariwisata, Majelis Ulama Indonesia Provinsi Nusa Tenggara Barat (NTB), serta Badan Promosi Pariwisata Daerah Nusa Tenggara Barat diharapkan dapat mempersiapkan secara SDM dan Kelembagaan untuk membantu pembangunan wisata halal di NTB; dan (3) Promosi, melakukan promosi pada sektor wisata halal, seperti mengikuti kegiatan atau menyelenggarakan event terkait wisata halal, seperti International Halal Food Fair, Seminar Wisata Halal Dunia, World Islamic Tourism Mart, dan yang lainnya. Serta, melakukan promosi melalui digital, seperti website, media sosial dan lainnya.

Adapun destinasi wisata halal yang ada di Lombok dapat dikunjungi wisatawan muslim diluncurkan oleh Association of The Indonesian Tours and Travel Agency atau Asosiasi Biro Perjalanan Wisata Indonesia (ASITA) wilayah Nusa Tenggara Barat membuat suatu paket perjalanan wisata halal yaitu 4 hari 3 malam. Pada hari pertama mulai kedatangan dari Bandara Internasional Lombok menuju ke Desa Sade kemudian ke Islamic Center. Pada hari kedua akan dibawa untuk mengetahui Masjid Kuno Karang Bayan, lalu ke daerah Sesaot, terus ke Jurang Malang sampai ke Air Terjun Benang Kelambu. Pada hari ketiga, wisatawan akan diajak menikmati keindahaan Gili Nanggu, Gili Kedis, dan Gili Sudak. Serta di hari keempat pengunjung akan diantar menuju kembali ke Bandara Internasional Lombok.45 Berikut ini gambaran secara umum tentang tujuan wisata yang menjadi paket perjalanan yang ditawarkan oleh ASITA.

Desa Sade adalah sebuah perkampungan suku asli sasak yang berjarak 30 dari pusat Kota Mataram dan tempat ini berada di Desa Rembitan, Kecamatan Pujut, Lombok Tengah, Nusa Tenggara Barat (NTB). Desa Sade ini hanya dihuni oleh 150 kepala keluarga yang bertujuan untuk menjaga kelestarian desa ini dan yang tinggal di Desa Sade ini adalah keluarga dari keturunan keenam belas dari leluhurnya. Dalam perkampungan ini terdapat rumah khas suku sasak dibangun dari bahan-bahan alami seperti tanah liat, sekam, dan beratapkan alang-alang. Tidak hanya bangunan sebagai tempat tinggal, dalam kampung ini ada beberapa istilah tempat tinggal, yaitu : bale tani, bale berugak, lumbung padi, bale kodong.

Bale Tani merupakan tempat tinggal sehari-hari yang terdiri dari bagian dalam, tempat anak gadis, memasak dan melahirkan. Bagian luar (sebelah kanan) untuk ibu bapak, dan sebelah kiri tempat anak laki-laki plus ruang tamu. Bale Berugak tempat pertemuan untuk memecahkan masalah, masalah perkawinan hingga sunatan. Sedangkan lumbung padi untuk menyimpan padi maupun hasil bumi lainnya, serta yang terakhir Bale Kodong untuk pasangan muda yang baru menikah. 
Masyarakat di Desa Sade ini mencari mata pencaharian dengan bertani, dan juga menenun untuk tambahan karena masih mengandalkan air hujan, sudah diupayakan untuk membuat irigasi tapi masih sulit. Selain itu, yang menarik juga tradisi suku sasak di Desa Sade itu sendiri yaitu 'kawin culik' atau Merariq.

Masjid Islamic Center Nusa Tenggara Barat, merupakan suatu bangunan megah masjid dengan motif sasambo menunjukkan karakteristik tiga suku yang ada di NTB yaitu, Sasak, Samawa, Mbojo. yang didirikan di atas tanah seluas 7,6 hektar yang berlokasi di pusat kota Mataram. Pembangunan Masjid Islamic Center NTB diresmikan pada 15 Desember 2013 yang dananya bersumber dari APBD (Anggaran Pendapatan dan Belanja Daerah) serta CSR (Corporate Social Responsibility) PT. Newmont. Islamic Center ini akan dijadikan sebagai pusat kebudayaan, wisata religi, pasar seni serta kegiatan wisata agama yang lainnya.

Masjid Karang Bayan, merupakan suatu masjid peninggalan bersejarah yang terletak di Desa Karang Bayan, Kecamatan Lingsar, Lombok Barat, memiliki bangunan seperti Masjid Beleq yang ada di Bayan, Lombok bagian Utara dianggap sebagai peninggalan dari Sunan Prapen pada abad ke 15 yang pertama kali menyebarkan Islam di Lombok. Masjid Kuno Karang Bayan ini di tanah seluas 4 are dengan panjang 7 meter dan lebar 6 meter, bangunan ini terdiri dari tembok yang berasal dari anyaman bambu dan atapnya memakai ijuk. Agar masjid ini tetap hidup, selalu diadakan pembelajaran Al-Qur'an selesai solat magrib.

Air Terjun Benang Kelambu, merupakan air terjun yang memiliki keindahan yang luar biasa, bernama benang kelambu karena air yang jatuh dari atas seperti korden, dalam bahasa sasak disebut kelambu. Air terjun ini terletak di bawah kaki Gunung Rinjani, berlokasi di Dusun Pemotoh, Desa Aik Berik, Kecamatan Batu Keliang Utara, Kabupaten Lombok Tengah. Jarak dari pusat kota yakni Kota Mataram, ibu kota Provinsi NTB ini sekitar 30 Kilometer. Indahnya air terjun yang asri ini konon airnya dipercaya dapat berguna untuk menyembuhkan berbagai macam penyakit dan untuk awet muda. Gili Nanggu, merupakan suatu pulau kecil yang secara geografis masuk ke kecamatan Sekotong, Kabupaten Lombok Barat. Untuk mengakses ke pulau tersebut dapat menyewa perahu yang disediakan oleh nelayan sekitar. Sedangkan, Gili Sudak, merupakan pulau kecil yang sangat mempesona terletak di Kecamatan Sekotong Barat, Desa Medang, Dusun Batu Kijuk, Lombok Barat. Tak jauh dari Gili Sudah, Gili Kedis, juga memiliki pesona tersendiri dengan ukuran paling kecil namun sangat indah dan hanya membutuhkan waktu sedikit untuk berkeliling pulau tersebut.

Selain yang disebutkan oleh ASTI, beberapa daerah juga dijadikan sebagai destinasi wisata halal, seperti Kawasan Ekonomi Khusus (KEK) Mandalika yang seluas 1.171.01 hektar tersebut, 250 hektarnya akan digunakan untuk kawasan wisata halal, karena memiliki potensi yang besar untuk pembangunan pariwisata halal di daerah ini. Selanjutnya adalah Desa Sembalun yang mendapat penghargaan sebagai World Best Halal Honeymoon Destination, desa ini memiliki daya tarik tersendiri karena merupakan gerbang terdekat menuju Gunung Rinjani yang memiliki ketinggian 1.156 meter dpl. Penduduk setempat menawarkan paket wisata dianataranya atraksi memanggil sapi dengan garam, memanggil burung, wisata keliling Desa Sembalun, memetik kopi dan cokelat, serta yang lainnya. Desa ini bisa ditempuh perjalanan selama dua jam dari pusat Kota Mataram. Serta masih banyak lagi daerah wisata halal yang dibangun oleh pemerintah daerah Nusa Tenggara Barat yang memiliki komitmen dalam membangun destinasi yang menjadi tujuan wisata keluarga terutama untuk wisatawan Muslim untuk mewujudkan Lombok sebagai destinasi wisata halal kelas dunia. 
Selain itu, terdapat kawasan strategis yang ditetapkan dalam Rencana Induk Pembangunan Kepariwisataan Daerah (RIPPARDA) tahun 2013-2028 menetapkan Kawasan Strategis Pariwisata Daerah (KSPD) sebagai berikut :

\begin{tabular}{|c|c|c|c|c|}
\hline KSPD & Mataram Metro & $\begin{array}{c}\text { Senggigi, Tiga } \\
\text { Gili }\end{array}$ & $\begin{array}{c}\text { Kuta } \\
\text { Mandalika }\end{array}$ & $\begin{array}{l}\text { Resimas } \\
\text { Sembalun }\end{array}$ \\
\hline Tema & 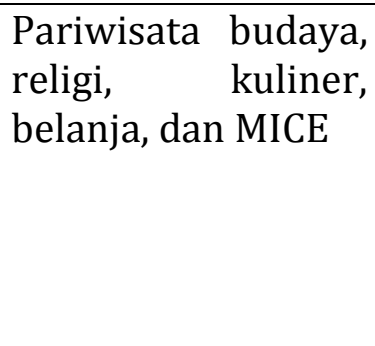 & $\begin{array}{l}\text { Pariwisata } \\
\text { pantai, bawah } \\
\text { laut, olah raga } \\
\text { berbasis } \\
\text { bahari, budaya, } \\
\text { religi dan } \\
\text { kuliner }\end{array}$ & $\begin{array}{l}\text { Pariwisata } \\
\text { pantai, bawah } \\
\text { laut, olah raga } \\
\text { bahari, dan } \\
\text { budaya }\end{array}$ & $\begin{array}{l}\text { Pariwisata } \\
\text { agro, } \\
\text { pegunungan, } \\
\text { budaya, dan } \\
\text { kuliner }\end{array}$ \\
\hline Lokasi & $\begin{array}{lr}\text { Kota } & \text { Mataram, } \\
\text { Islamic } & \text { Center, } \\
\text { Loang } & \text { Baloq, } \\
\text { Taman } & \text { Mayura, } \\
\text { Sekarbela, } \\
\text { Banyumulek, } \\
\text { Taman Narmada, } \\
\text { Suranadi, Lingsar }\end{array}$ & $\begin{array}{l}\text { Batu layar, } \\
\text { Batu Bolong, } \\
\text { Senggigi, Tiga } \\
\text { Gili } \\
\text { (Trawangan, } \\
\text { Meno, Air), } \\
\text { Sindang Gile, } \\
\text { Senaru, Dusun } \\
\text { Tradisional, } \\
\text { Segenter }\end{array}$ & $\begin{array}{l}\text { Gili gede, Gili } \\
\text { nanggu, } \\
\text { BangkoBangk } \\
\text { o, Selong } \\
\text { Belanak, Sade, } \\
\text { Kuta, Gili } \\
\text { Indah }\end{array}$ & $\begin{array}{l}\text { Benang Stokel, } \\
\text { Gili Sulat, } \\
\text { Sembalun, } \\
\text { Gunung } \\
\text { Rinjani, Otak } \\
\text { kokoq }\end{array}$ \\
\hline
\end{tabular}

Tabel 1. Kawasan Strategis Pariwisata Daerah Pulau Lombok Tahun 2015-2019.

\section{Upaya Mewujudkan Akomodasi Halal Berdasarkan Peraturan Daerah Propinsi Nusa Tenggara Barat Nomor 2 Tahun 2016 Tentang Pariwisata Halal.}

Dalam rangka untuk mewujudkan akomodasi halal berdasarkan Peraturan Daearh Propinsi Nusa Tenggara Barat Nomor 2 Tahun 2016 tentang Pariwisata Halal, maka pemerintah propinsi NTB mengeluarkan Peraturan Daerah Nomor 2 Tahun 2016 tentang Pariwisata Halal.

Berdasarkan ketentuan Pasal 14 Peraturan Daerah Nusa Tenggara Barat Nomor 2 Tahun 2016 tentang pariwisata halal menyebukan :

(1) Dalam Pariwisata Halal harus memiliki akomodasi sesuai standar syariah.

(2) Standar syari'ah sebagaimana dimaksud pada ayat (1) setelah memperoleh sertifikasi dari DSN-MUI.

(3) Standar syari'ah sebagaimana dimaksud pada ayat (1) meliputi aspek: a. produk; b. pelayanan; dan c. pengelolaan.

Dalam hal standar syariah sebagaimana dimaksud pada ayat (2) belum terpenuhi, maka akomodasi paling sedikit memenuhi hal-hal sebagai berikut: (a) Tersedia fasilitas yang layak untuk bersuci; (b) Tersedia fasilitas yang memudahkan untuk beribadah; (c) Tersedia makanan dan minuman halal; (d) Fasilitas dan suasana yang aman, nyaman dan kondusif untuk keluarga dan bisnis; dan (f) Terjaga kebersihan sanitasi dan lingkungan.

Selain menerbitkan perda tersebut Pemerintah Propinsi Nusa Tenggara Barat juga melakukan upaya untuk menciptakan pengelolaan prinsip kepariwisataan berdasarkan syariah, diantaranya :

1. Destinasi Wisata Ramah Keluarga

Tujuan wisata ramah keluarga ini merupakan untuk mengakomodasi wisatawan Muslim yang berwisata karena memiliki karakter dalam berwisata sering berwisata bersama keluarga. Jadi, dengan seperti itu wisatawan Muslim dapat melakukan kegiatan 
wisata dengan nyaman dan aman bersama keluarganya. Untuk itu, Pemerintah Provinsi Nusa Tenggara Barat (NTB) bersama Asosiasi Travel Agent Indonesia Provinsi NTB memberikan paket perjalanan wisata selama tiga hari empat malam dengan tujuan wisata mulai dari Desa Sade, Islamic Center NTB, Masjid Kuno Karang Bayan, Sesaot, Air Terjun Benang Kelambu, Gili Nanggu, Gili Kedis Gili Sudak. Serta beberapa kawasan strategis lainnya.

2. Layanan dan Fasilitas Wisatawan Muslim

a. Pilihan Makanan Dengan Jaminan Halal

Salah satu kebutuhan dasar dari wisatawan Muslim adalah adanya fasilitas makanan dan minuman yang memiliki jaminan halal tersedia saat melakukan wisata. Untuk memenuhi hal tersebut, jaminan halal di NTB dilakukan oleh kerja sama antara Pemerintah Daerah Provinsi NTB dalam hal ini Dinas Kebudayaan dan Pariwisata bersama Majelis Ulam Indonesia serta Lembaga Pengkajian Pangan, Obat-Obatan, dan Kosmetik (LPPOM) dan juga Dinas Koperasi dan Usaha Mikro Kecil dan Menengah (UMKM) melakukan sertifikasi halal untuk UMKM, Rumah Makan, Restoran Hotel, Serta Restoran Non Hotel pada tahun 2016 sudah terdaftar 644 sertifikasi halal.

b. Kemudahan Akses Ibadah

Akses kemudahan dalam melakukan ibadah juga menjadi sangat penting dalam melakukan wisata karena menjalankan suatu kewajiban sebagai seorang Muslim salah satunya adalah melakukan solat. Sebagai daerah dengan populasi Muslim hingga 90 persen dan daerah yang dijuluki dengan Pulau Seribu Masjid, masjid dengan mudah dapat ditemukan, hampir setiap desa memiliki minimal satu masjid, masjid tersebar hingga 4.500 di 598 desa dan kelurahan. Selain itu, pusat perbelanjaan dan destinasi wisata biasanya menyediakan bilik tersendiri bagi wisatawan yang ingin melakukan ibadah.

c. Fasilitas Bandar Udara

Fasilitas airport juga menjadi salah satu indikator dalam melihat layanan dan fasilitas wisatawan Muslim, bandar udara tersebut memiliki kemudahan untuk akses ibadah seperti tempat solat, perlengkapan solat, tempat wudhu atau toilet yang memisahkan antara perempuan dan laki-laki. Bandara Internasional Lombok, merupakan satu-satunya bandar udara di NTB sebagai pintu masuk kedatangan wisatawan domestik maupun manca negara saat ini dilengkapi dengan fasilitas yang cukup bagi wisatawan Muslim untuk beribadah seperti ada tiga musholla di area raung tunggu domestik, ruang tunggu internasional, dan Loby Lantai 1 Terminal serta memiliki satu masjid di area Bandara.

\section{SIMPULAN}

Deskripsi akomodasi pariwisata di Lombok sebelum dan sesudah lahirnya Peraturan Daerah Propinsi Nusa Tenggara Barat Nomor Tahun 2016 tentang Pariwisata Halal adalah sebagai berikut sebelum lahirnya Perda tersebut pengelolaan pariwisata di Propinsi Nusa Tenggra Barat tidak berbasis syariah atau konvensional, setelah lahirnya Perda Nomor 2 Tahun 2016 pengelolaan pariwisata di Propinsi Nusa Tenggara Barat berbasis syariah.

Upaya Mewujudkan Akomodasi Halal Berdasarkan Peraturan Daerah Propinsi Nusa Tenggara Barat Nomor 2 Tahun 2016 Tentang Pariwisata Halal adalah dengan melakukan upaya review terhadap master plan pembangunan kepariwisataan Nusa Tenggara Barat dengan meingkatkan layanan dan akomodasi bagi wisatawan domistik maupun wisatawan mancaanegara. 


\section{DAFTAR PUSTAKA}

[1] Abdullah, dkk, 1994. Pengantar Kompilasi Hukum Islam dalam Tata Hukum Indonesia, Jakarta: Gema Insani Press.

[2] BPS. (2010). Retrieved April 30, 2015, from Biro Pusat Statistik: http://sp2010.bps.go.id/index.php/site/tabel?tid=321

[3] Battour, M., \& Ismail, M. N. 2014. Islamization Trends-Implcation for Tourism Market. Islamic Tourism Journal.

[4] Chookaew, S. (2015). Increasing Halal Tourism Potential at Andaman Gulf in Thailand for Muslim Country. Journal of Economics, Business and Management.

[5] Ghadami, M. (2012). The Role of Islam in the Tourism Industry. Elixir Management Arts.

[6] http://www.parekraf.go.id/asp/detil.asp?id=2555

[7] Mohammad Daud, 2013. Hukum Islam Pengantar Ilmu Hukum dan Tata Hukum Islam di Indonesia, Jakarta: PT RjaGrafindo Persada,.

[8] Kamarudin, L. M. (2013). Islamic Tourism: The Impacts to Malaysia's Tourism Industry. Proceedings of International Conference on Tourism Development.

[9] Ismayanti. (2010). Pengantar Pariwisata. Jakarta: Grasindo.

[10] Peraturan Daerah Nomor 2 Tahun 2016 tentang Pariwisata Halal di Nusa Tenggara Barat

[11] Sri Wahyuningsih, Potensi Pariwsata Halal di Nusa Tenggara Barat, Makalah disampaikan pada kuliah umum tanggal 23 Juni 2017

[12] Siaran Pers Menteri Pariwisata Dan Ekonomi Kreatif. (2014, Maret 18). Retrieved April 30, 2015, from kemenparekraf:

[13] Tourism Review. (2013, April 01). Retrieved April 30, 2015, from TourismReview: http://www.tourism-review.com/indonesia-launches-sharia-tourismprojectsnews 